\title{
ANALISIS PENGARUH STRUKTUR MODAL TERHADAP PROFITABILITAS UMKM DI KOTA TASIKMALAYA
}

\author{
Rita Tri Yusnita1, Budhi Wahyu Fitriadi ${ }^{2}$ \\ 1,2 Program Studi Manajemen FE Universitas Perjuangan Tasikmalaya \\ *Email Corresponding Author : tryusnita@yahoo.com
}

\begin{abstract}
This study aims to determine and analyze the influence of capital structure on the profitability of Micro, Small and Medium Enterprises (MSMEs) in the city of Tasikmalaya. The research objectives are described in three objectives, namely knowing and analyzing 1) the effect of short-term debt on profitability, 2) the effect of long-term debt on profitability, and 3) the effect of total debt on profitability. The method used in this study is a survey method with a sample of 30 MSMEs that are considered representative of the MSME population in the city of Tasikmalaya. The data analysis used in this study is multiple linear regression analysis with the help of SPSS software. The results showed that Short-term Debt to Asset had a positive and significant effect on the profitability of MSMEs in the city of Tasikmalaya, Long-term Debt to Asset had a positive and significant effect on the profitability of MSMEs in the city of Tasikmalaya, while Total Debt to Asset had a negative but insignificant effect towards the profitability of MSMEs in the city of Tasikmalaya.
\end{abstract}

Key Words: Size firm, profitability, capital structure

\begin{abstract}
ABSTRAK
Penelitian ini bertujuan untuk mengetahui dan menganalisis pengaruh struktur modal terhadap profitabilitas Usaha Mikro Kecil dan Menengah (UMKM) yang ada di lingkungan kota Tasikmalaya. Tujuan penelitian diuraikan dalam tiga tujuan, yaitu mengetahui dan menganalisis 1) pengaruh hutang jangka pendek terhadap profitabilitas, 2) pengaruh hutang jangka panjang terhadap profitabilitas, dan 3) pengaruh total hutang terhadap profitabilitas. Metode yang digunakan dalam penelitian ini adalah metode survei dengan sampel sebanyak 30 UMKM yang dianggap representatif dari populasi UMKM di lingkungan kota Tasikmalaya. Analisis data yang digunakan dalam penelitian ini adalah analisis regresi linier berganda dengan bantuan software SPSS.

Hasil penelitian menunjukkan bahwa Short-term Debt to Asset berpengaruh positif dan signifikan terhadap profitabilitas UMKM di lingkungan kota Tasikmalaya, Long-term Debt to Asset berpengaruh positif dan signifikan terhadap profitabilitas UMKM di lingkungan kota Tasikmalaya, sedangkan Total Debt to Asset berpengaruh negatif namun tidak signifikan terhadap profitabilitas UMKM di lingkungan kota Tasikmalaya.
\end{abstract}

Kata Kunci: Ukuran perusahaan, profitabilitas, struktur modal

\section{PENDAHULUAN}

Usaha Mikro Kecil dan Menengah (UMKM) pada saat ini menjadi salah satu bidang usaha yang menopang perekonomian Indonesia. UMKM terbukti mampu bertahan dari krisis ekonomi yang terjadi beberapa tahun yang lalu.

Selama ini UMKM telah memberikan kontribusi pada Produk Domestik Bruto (PBD) sebesar 57\% - 60\% dan tingkat penyerapan tenaga kerja sekitar 97\% dari seluruh tenaga kerja nasional (LPPI dan BI tahun 2015). 
Data dari Kementerian Koperasi dan Usaha Kecil Menengah pada tahun 2014, terdapat sekitar 57,8 juta pelaku UMKM di Indonesia. Di tahun 2017 serta beberapa tahun ke depan diperkirakan jumlah pelaku UMKM akan terus bertambah.

Perkembangan UMKM yang cukup tinggi pada saat ini tidak terlepas dari masalah, khususnya masalah permodalan. Masalah ini dikarenakan sebagian besar UMKM merupakan usaha keluarga yang diturunkan secara turun menurun, sehingga modal yang dimiliki tidak terlalu besar. Pada umumnya modal yang diperoleh UMKM berasal dari modal sendiri dan pinjaman dari pihak keluarga.

Pemerintah sangat menyadari pentingnya pengembangan usaha mikro usaha kecil dan usaha menengah. Pemerintah melalui Bank Indonesia telah mengeluarkan ketentuan yang mewajibkan kepada perbankan untuk mengalokasikan kredit/pembiayaan kepada UMKM mulai tahun 2015 sebesar 5\%, tahun 2016 sebesar 10\%, tahun 2017 sebesar 15\% dan pada akhir tahun 2018 sebesar 20\%. Hal tersebut berdasarkan Peraturan Bank Indonesia (PBI) No. 17/12/PBI/2015 tanggal 25 Juni 2015 tentang Perubahan atas Peraturan Bank Indonesia No. 14/22/PBI/2012, dan PBI No. 14/22/PBI/2012 tentang Pemberian Kredit atau Pembiayaan oleh Bank Umum dan Bantuan Teknis dalam rangka Pengembangan Usaha Mikro, Kecil dan Menengah yang disertai ketentuan pendukungnya, yang mana dalam PBI dimaksud diwajibkan untuk mengalokasikan kredit/pembiayaan kepada UMKM, secara bertahap mulai dari 5\% pada tahun 2015 hingga mencapai 20\% akhir tahun 2018.

Menurut data Bank Indonesia, setiap tahunnya kredit yang disalurkan kepada UMKM mengalami pertumbuhan. Walaupun pada tahun 2015, sekitar 60\% - 70\% dari seluruh sektor UMKM belum mempunyai akses pembiayaan melalui perbankan.

Dukungan pemerintah berupa penyaluran kredit terhadap UMKM, memberikan peluang bagi UMKM untuk dapat mempertahankan dan mengembangkan usahanya. Dengan dana yang mencukupi akan sangat membantu kelancaran operasional usaha UMKM sehingga tujuan perusahaan / UMKM dapat tercapai, yaitu perolehan laba optimal. Laba sering digunakan untuk mengukur tingkat keberhasilan suatu usaha. Sebuah usaha dikatakan berkembang atau maju apabila laba yang mereka peroleh terus meningkat dari tahun ke tahun. Laba juga sering digunakan untuk melihat going concern suatu usaha. Sejauh mana UMKM mampu menghasilkan laba dapat dilihat dari kinerja profitabilitasnya.

Kredit yang diberikan kepada UMKM, di satu sisi, dapat memberikan tambahan dana sehingga memungkinkan berjalannya dan berkembangnya operasi usaha UMKM, namun di sisi lain, dapat menjadikan beban bagi UMKM karena selain harus mengembalikan dana pinjaman tersebut juga memiliki kewajiban membayar biaya modal, yaitu bunga atas pinjaman tersebut. Besaran hutang yang dimiliki UMKM akan mempengaruhi struktur modal UMKM, dan struktur modal dapat mempengaruhi perolehan laba bersih UMKM.

Data dari Perkumpulan Akses Keuangan Indonesia (Pakindo) tahun 2016, menyebutkan bahwa 60\% UMKM mengalami kesulitan dalam mengelola arus kas untuk memenuhi kewajiban pembayaran angsuran pinjaman. Sementara itu, sebanyak 54\% nasabah UMKM ternyata memiliki 3 (tiga) jenis pinjaman di lembaga keuangan mikro. Pakindo mengatakan bahwa hal tersebut dipicu oleh banyaknya lembaga keuangan mikro yang menawarkan pinjaman dengan proses yang mudah, sehingga mengakibatkan nasabah UMKM mengambil pinjaman berganda.

Berdasarkan kondisi tersebut, penulis melakukan penelitian untuk melihat sejauh mana pengaruh struktur modal terhadap profitabilitas UMKM, khususnya UMKM yang terdapat di lingkungan kota Tasikmalaya. Berdasarkan data pemerintah Kota Tasikmalaya jumlah UMKM unggulan pada tahun 2015 sebanyak 2.888 unit yang terdiri dari usaha bordir, kerajinan bambu, kerajinan mendong, alas kaki, meubel, batik, payung geulis, dan makanan. 


\section{TINJAUAN PUSTAKA}

\section{Struktur Modal}

Struktur Modal merupakan hal penting dalam sebuah perusahaan, dimana di dalamnya terdapat perpaduan antara utang beserta ekuitas atau biasa diartikan sebagai perimbangan antara modal asing dan modal sendiri. Modal asing terdiri dari utang jangka panjang maupun jangka pendek. Sedangkan modal sendiri terbagi atas laba ditahan dan bisa juga dengan penyertaan kepemilikan perusahaan.

Struktur modal adalah perimbangan atau perbandingan antara jumlah hutang jangka panjang dengan modal sendiri (Bambang Riyanto, 2010 : 282). Pendapat lain mengatakan bahwa struktur modal merupakan perimbangan jumlah hutang jangka pendek yang bersifat permanen, hutang jangka panjang, saham preferen, dan saham biasa (Agus Sartono, 2011 : 225).

Untuk melihat bagaimana struktur modal suatu perusahaan dapat menggunakan rasio utang, yang terdiri dari:

Short-term Debt to Asset (STD) atau utang jangka pendek atas total asset

$$
S T D=\frac{\text { Jumlah Utang Jangka Pendek }}{\text { Total Aset }}
$$

Long-term Debt to Asset (LTD) atau utang jangka panjang atas total asset

$$
L T D=\frac{\text { Jumlah Utang Jangka Panjang }}{\text { Total Aset }}
$$

Total Debt to Asset (TDA) atau total utang atas total asset

$$
T D A=\frac{\text { Utang Jangka Pendek }+ \text { Utang Jangka Panjang }}{\text { Total Aset }}
$$

\section{Profitabilitas}

Profitabilitas merupakan gambaran dari kinerja manajemen dalam mengelola perusahaan. Menurut Agus Sartono (2011:122) Profitabilitas adalah kemampuan perusahaan memperoleh laba dalam hubungannya dengan penjualan, total aktiva maupun modal sendiri. Sedangkan Ridwan Tobing dan Nirwan Talankky (2004: 263) mendefinisikan profitabilitas sebagai kemampuan perseroan untuk memperoleh laba dan potensi untuk memperoleh penghasilan pada masa yang akan datang yang dapat diukur dengan Return on Equity (ROE) dan Return on Assets (ROA).

Rasio profitabilitas akan memberikan gambaran tentang tingkat efektifitas pengelolaan perusahaan. Semakin besar rasio, akan semakin baik, karena kemakmuran pemilik perusahaan meningkat dengan semakin besarnya profitabilitas. Rasio profitabilitas yang seringkali dipergunakan karena kemudahannya dalam menghitung adalah:

\section{Return on Assets (Hasil Pengembalian atas Total Aktiva)}

$$
\text { Return on Assets }=\frac{\text { Net Income }}{\text { Total Assets }}
$$

Rasio ini digunakan untuk mengukur kemampuan perusahaan dalam menghasilkan laba dengan menggunakan total aktiva yang ada dan setelah biaya-biaya modal (biaya yang digunakan mendanai aktiva) dikeluarkan dari analisis. 


\section{Return on Equity (Hasil Pengembalian atas Ekuitas)}

Rasio ini memperlihatkan sejauh mana perusahaan mengelola modal sendiri (net worth) secara efektif, mengukur tingkat keuntungan dari investasi yang telah dilakukan pemilik modal sendiri atau pemegang saham perusahaan.

Return on Equity (ROE) menunjukkan rentabilitas modal sendiri atau sering juga disebut rentabilitas usaha.

Return on Equity $=\frac{\text { Net Income }}{\text { Net } \text { Worth }}$

\section{PERUMUSAN HIPOTESIS}

Keputusan struktur modal merupakan keputusan yang penting dalam perusahaan. Keputusan ini penting karena perlu mengoptimalkan return sehingga biaya yang ditimbulkan akibat keputusan pemilihan penggunaan modal dapat ditekan. Struktur modal merupakan perimbangan jumlah hutang jangka pendek yang bersifat permanen, hutang jangka panjang, saham preferen, dan saham biasa (Agus Sartono, 2011 : 225).

Kebanyakan perusahaan tidak bisa lepas dari penggunaaan hutang. Ketika modal sendiri tidak mencukupi untuk kelancaran operasional perusahaan maka penggunaan hutang memberikan solusi tambahan dana agar perusahaan dapat tetap beroperasi dan bahkan melakukan pengembangan usahanya sehingga dapat meningkatkan laba. Dan sebaliknya, jika dana tidak mencukupi akan mengganggu kegiatan operasional usaha perusahaan sehingga perusahaan akan kesulitan memperoleh laba. Penggunaan hutang dapat mengungkit kemampulabaan perusahaan, mengungkit kemampuan perusahaan untuk memperoleh laba lebih besar. Hal tersebut memperlihatkan bahwa penggunaan hutang mampu meningkatkan kemampulabaan perusahaan.

Namun harus diperhatikan pula, bahwa jika modal pinjaman terlalu besar akan meningkatkan risiko tidak terbayarnya beban tetap berupa bunga dan pinjaman pokoknya tanpa melihat perusahaan dalam keadaan untung atau rugi.

David Sukardi Kodrat (2009) dalam jurnalnya menyatakan bahwa penggunaan utang baik jangka pendek maupun jangka panjang berpengaruh terhadap penurunan profitabilitas.

Said Kelana Asnawi dan Chandra Wijaya (2006 : 166), menyatakan bahwa struktur modal yang mempengaruhi laba adalah hutang, karena hutang memiliki biaya (bunga yang dibayar) yang akan mengurangi jumlah laba yang diperoleh. Makin besar hutang yang dipakai maka biaya bunga juga makin besar, sehingga laba makin kecil. Namun demikian makin besar hutang yang dipakai, maka modal sendiri yang diperlukan makin kecil. Karenanya walaupun laba yang diperoleh makin kecil, namun modal sendiri pun yang dipakai makin kecil.

Sejalan dengan pemikiran di atas, Ali Kesuma (2009), mengemukakan bahwa semakin besar angka rasio struktur modal berarti semakin banyak jumlah pinjaman jangka panjang, sehingga semakin banyak bagian dari laba operasi yang digunakan untuk membayar beban bunga tetap, dan semakin banyak aliran kas yang digunakan untuk membayar angsuran pinjaman, akibatnya semakin sedikit jumlah laba bersih sesudah pajak yang akan diterima oleh perusahaan.

Hutang merupakan pengorbanan manfaat ekonomi yang timbul karena kewajiban suatu entitas untuk menyerahkan asset atau memberikan jasa kepada entitas lain di masa mendatang sebagai akibat transaksi masa lalu (Chariri dan Ghozali, 2007).

Peningkatan hutang akan mempengaruhi besar kecilnya laba perusahaan, yang mencerminkan kemampuan perusahaan dalam memenuhi semua kewajibannya, yang ditunjukkan oleh beberapa bagian modal sendiri yang digunakan untuk membayar seluruh 
kewajibannya, karena semakin besar penggunaan utang maka akan semakin besar kewajibannya.

Hutang digolongkan menjadi utang jangka pendek dan utang jangka panjang. Utang jangka pendek adalah utang-utang yang akan jatuh tempo dalam satu tahun atau dalam satu siklus kegiatan normal perusahaan. Sedangkan utang jangka panjang merupakan utang yang jatuh temponya lebih dari satu tahun.

Hutang dalam struktur modal perusahaan dapat diproksikan dengan Short-term Debt to Asset (STD) atau Hutang Jangka Pendek atas Total Aset, Long-term Debt to Asset (LTD) atau Hutang Jangka Panjang atas Total Aset, dan Total Debt to Asset (TDA) atau Total Hutang atas Total Aset. Struktur modal yang baik diharapkan akan dapat meminimumkan penggunaan biaya modal sehingga dapat meningkatkan profitabilitas.

Profitabilitas adalah kemampuan suatu perusahaan untuk menghasilkan laba selama suatu periode tertentu. Terdapat beberapa rasio keuangan yang umumnya dipergunakan untuk menilai tingkat profitabilitas suatu perusahaan, seperti Gross Profit Margin, Net Profit Margin, Return on Assets (ROA), dan Return on Equity (ROE). Indikator yang digunakan penulis untuk mengetahui tingkat profitabilitas perusahaan dalam penelitian ini adalah Return on Assets (ROA).

Secara teoritis, penggunaan hutang dapat meningkatkan profitabilitas di satu sisi, namun di sisi lain dalam kondisi tertentu justru dapat pula menurunkan profitabilitas. Dampak penggunaan hutang terhadap profitabilitas dapat dilihat pula dari beberapa hasil penelitian yang pernah dilakukan.

Gill et al. (2011) menemukan hubungan positif antara utang jangka pendek atas total aset dan profitabilitas. Penelitian dilakukan pada perusahaan jasa dan perusahaan manufaktur di Amerika yang listing di New York Stock Exchange (Bursa Efek New York) untuk periode tiga tahun. Namun Mendell et al. (dalam Gill et al., 2011) menemukan hubungan negatif antara profitabilitas dan utang. Kemudian penelitian yang dilakukan oleh Abor J (2005) menunjukkan bahwa utang jangka pendek terhadap total asset memiliki hubungan positif terhadap profitabilitas. Ini menunjukkan bahwa utang jangka pendek cenderung lebih kecil, oleh karena itu, dengan meningkatkan utang jangka pendek dengan tingkat bunga yang relatif rendah akan menyebabkan peningkatan tingkat profitabilitas.

Gill et al. (2011) juga menemukan hubungan positif antara utang jangka panjang atas total aset dan profitabilitas. Melalui analisis regresi, Wald (dalam Gill et al., 2011) menemukan adanya korelasi negatif antara leverage dan profitabilitas. Penelitian Abor J (2005) juga menemukan bahwa utang jangka panjang terhadap total asset berpengaruh negatif terhadap profitabilitas.

Gill et al. (2011) menemukan hubungan positif antara total utang atas total asset terhadap profitabilitas. Chiang (2002) melalui analisis regresi mengindikasikan bahwa profitabilitas dan struktur modal saling terkait. Data yang mereka kumpulkan berkaitan dengan 18 pengembang dan 17 kontraktor dari Hongkong dengan menggunakan Data Stream (database keuangan elektronik). Hasil penelitian Abor (2005) menemukan asosiasi positif antara rasio total utang pada total aset dan Return On Equity. Supianto, Witarsa, Warneri (2012) menggunakan sampel perusahaan makanan minuman yang terdaftar di BEI periode 2008-2011. Dalam penelitiannya, mereka menemukan bahwa rasio utang yang diukur dengan DER tidak terdapat pengaruh signifikan terhadap profitabilitas yang diukur menggunakan ROI.

Penelitian yang dilakukan Astuti, Retnowati, dan Rosyid (2015) terhadap 100 Perusahaan Terbaik Versi Majalah Fortune Indonesia menunjukkan bahwa hutang jangka panjang (Long Term Debt to Asset Ratio) memiliki pengaruh negatif dan signifikan terhadap ROE, sedangkan Total Hutang (Total Debt to Asset Ratio) memiliki pengaruh positif dan signifikan terhadap ROE.

Berdasarkan kerangka pemikiran di atas, maka hipotesis dalam penelitian ini adalah : H1 : Short-term Debt to Asset berpengaruh terhadap profitabilitas.

H2 : Long-term Debt to Asset berpengaruh terhadap profitabilitas. 
H3 : Total Debt to Asset berpengaruh terhadap profitabilitas.

\section{METODE PENELITIAN}

Metode penelitian yang digunakan adalah metode deskriptif analitis dengan pendekatan survei. Ukuran sampel ditetapkan sebesar 30 dan penarikan sampel didasarkan pada purposive sampling. Adapun identitas perusahaan tidak penulis tampilkan secara jelas dengan pertimbangan untuk melindungi kerahasiaan UMKM sebagai sampel dikarenakan terdapat beberapa UMKM yang tidak menginginkan nama perusahaannya dipublikasi.

\section{Operasionalisasi Variabel}

Dalam penelitian ini penulis melakukan analisis pada besarnya pengaruh yang ditimbulkan variabel independen terhadap variabel dependen, yaitu pengaruh struktur modal terhadap profitabilitas.

Variabel independen $\mathrm{X}$ diukur atau diaproksikan dengan menggunakan rasio utang, yang terdiri dari Short-term Debt to Asset (STD) (X1), Long-term Debt to Asset (LTD) (X2), dan Total Debt to Asset (TDA) (X3). Variabel terikat Y yaitu Profitabilitas (Y) diukur dengan Return on Assets (ROA).

Tabel 1

Operasionalisasi Variabel

\begin{tabular}{|c|c|c|c|}
\hline Variabel & Definisi Variabel & Indikator & Skala \\
\hline $\begin{array}{c}\text { Short-term } \\
\text { Debt to Asset } \\
\left(\mathrm{X}_{1}\right)\end{array}$ & $\begin{array}{l}\text { Short-term Debt to Asset menunjukkan } \\
\text { seberapa besar hutang jangka pendek yang } \\
\text { digunakan untuk investasi ke dalam aktiva } \\
\text { guna menghasilkan keuntungan (Warsono, } \\
\text { 2009:133). }\end{array}$ & $\begin{array}{l}\text { Total Utang } \\
\text { Jangka Pendek } \\
\text { dibagi Total Aset }\end{array}$ & Rasio \\
\hline $\begin{array}{c}\text { Long-term } \\
\text { Debt to Asset } \\
\left(\mathrm{X}_{2}\right)\end{array}$ & $\begin{array}{l}\text { Long-term Debt to Asset menunjukkan } \\
\text { seberapa besar hutang jangka panjang yang } \\
\text { digunakan untuk investasi ke dalam aktiva } \\
\text { guna menghasilkan keuntungan (Warsono, } \\
\text { 2009: 134). }\end{array}$ & $\begin{array}{l}\text { Total Utang } \\
\text { Jangka Panjang } \\
\text { dibagi Total Aset }\end{array}$ & Rasio \\
\hline $\begin{array}{c}\text { Total Debt to } \\
\text { Asset } \\
\left(\mathrm{X}_{3}\right)\end{array}$ & $\begin{array}{l}\text { Total Debt to Total Assets Ratio } \\
\text { merupakan rasio utang yang digunakan } \\
\text { untuk mengukur perbandingan antara } \\
\text { total hutang dengan total aktiva. } \\
\text { Dengan kata lain, seberapa besar aktiva } \\
\text { perusahaan dibiayai oleh hutang atau } \\
\text { seberapa besar hutang perusahaan } \\
\text { berpengaruh terhadap pengelolaan aktiva } \\
\text { (Mamduh M Hanafi dan Abdul Halim } \\
(2012: 79) \text { ) }\end{array}$ & $\begin{array}{l}\text { Total Utang } \\
\text { dibagi Total Aset }\end{array}$ & Rasio \\
\hline
\end{tabular}




\begin{tabular}{clcc}
\hline $\begin{array}{c}\text { Profitabilita } \\
\text { s (Y) }\end{array}$ & $\begin{array}{l}\text { Profitabilitas merupakan kemampuan } \\
\text { perseroan untuk memperoleh laba dan }\end{array}$ & $\begin{array}{c}\text { Return on Asset } \\
\text { (Laba Bersih }\end{array}$ & Rasio \\
& potensi untuk memperoleh penghasilan & dibagi Total & \\
& pada masa yang akan datang yang dapat & Aset) & \\
diukur dengan Return on Equity (ROE) dan & & \\
& Return on Assets (ROA) (Ridwan Tobing dan & \\
& Nirwan Talankky; 2004: 263) &
\end{tabular}

\section{Teknik Analisis Data}

Dalam penelitian ini terdapat empat variabel, dimana tiga variabel merupakan variabel bebas

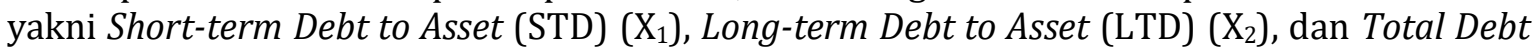
to Asset (TDA) (X3) serta satu variabel terikat/variabel dependen (Dependent Variable) yaitu Profitabilitas (Y) yang diukur dengan Return on Assets (ROA), maka alat analisis yang digunakan adalah analisis regresi berganda yang diterjemahkan dalam sebuah diagram dalam Gambar 1.

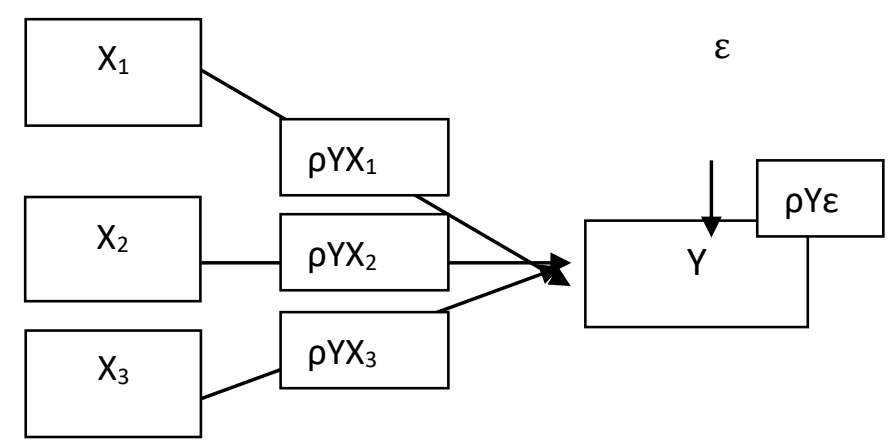

Gambar 1

Struktur Lengkap Regresi Ganda

Sedangkan model persamaannya adalah sebagai berikut:

$$
\mathrm{Y}=\mathrm{a}+\mathrm{b}_{1} \mathrm{X}_{1}+\mathrm{b}_{2} \mathrm{X}_{2}+\mathrm{b}_{3} \mathrm{X}_{3}+\mathrm{e}
$$

Keterangan:

$\mathrm{Y}=$ Profitabilitas (Return on Assets (ROA)).

$\mathrm{X}_{1}=$ Short-term Debt to Asset

$\mathrm{X}_{2}=$ Long-term Debt to Asset

$\mathrm{X}_{3}=$ Total Debt to Asset

$\mathrm{a}=$ nilai $Y$ jika $\mathrm{X}=0$ (nilai konstanta)

$\mathrm{b}=$ koefisien regresi

$\mathrm{e}=$ kesalahan baku estimasi regresi

\section{HASIL PENELITIAN DAN PEMBAHASAN}

\section{Struktur Modal UMKM Kota Tasikmalaya}

Struktur modal UMKM Kota Tasikmalaya dapat dilihat dari 3 (tiga) rasio struktur modal yang umum digunakan, yaitu Short-term Debt to Asset (STD), Long-term Debt to Asset (LTD), dan Total Debt to Asset (TDA).

Nilai Short-term Debt to Asset rata-rata dari ketigapuluh UMKM kota Tasikmalaya adalah sebesar 0,073497 atau sebesar 7,35 \%, yang mengandung makna bahwa rata-rata 
aktiva atau aset perusahaan UMKM kota Tasikmalaya dibiayai dengan hutang jangka pendek sebesar 7,35\%.

Nilai Long-term Debt to Asset rata-rata dari ketigapuluh UMKM kota Tasikmalaya adalah sebesar 0,2558 atau sebesar 25,58 \%, yang mengandung makna bahwa rata-rata aktiva atau aset perusahaan UMKM kota Tasikmalaya dibiayai dengan hutang jangka panjang sebesar $25,58 \%$.

Nilai Total Debt to Asset rata-rata dari ketigapuluh UMKM kota Tasikmalaya adalah sebesar 0,2960 atau sebesar 29,6\%, yang mengandung makna bahwa rata-rata aktiva atau aset perusahaan UMKM kota Tasikmalaya dibiayai dengan hutang jangka pendek dan hutang jangka panjang sebesar $29,6 \%$.

\section{Profitabilitas UMKM Kota Tasikmalaya}

Nilai Return on Assets (ROA) rata-rata dari ketigapuluh UMKM kota Tasikmalaya adalah sebesar 0,7691 atau sebesar 76,91\%, yang mengandung makna bahwa kemampuan UMKM dalam menghasilkan laba dari aktiva perusahaan yang digunakan sebesar 76,91\%. Hal ini menunjukkan bahwa secara rata-rata, UMKM kota Tasikmalaya mampu menghasilkan Rp 0,769,- keuntungan bersih operasi dari Rp 1,- aktiva perusahaan yang digunakan.

\section{Pengaruh Struktur Modal Terhadap Profitabilitas UMKM Kota Tasikmalaya}

Pengaruh Short-term Debt to Asset Terhadap Profitabilitas UMKM Kota Tasikmalaya

Dari hasil output SPSS diperoleh nilai koefisien korelasi antara Short-term Debt to Asset dengan profitabilitas sebesar 0,768 yang menunjukkan keeratan hubungan antara Short-term Debt to Asset dengan profitabilitas tersebut masuk kategori kuat.

Nilai koefisien korelasi yang positif menunjukkan bahwa Short-term Debt to Asset berkorelasi positif dengan profitabilitas, hal ini menunjukkan bahwa semakin besar rasio Short-term Debt to Asset dalam batas tertentu maka akan semakin meningkatkan profitabilitas, dan sebaliknya, semakin kecil rasio Short-term Debt to Asset maka akan semakin kecil profitabilitas. Hal ini menunjukkan bahwa hutang jangka pendek, dalam batas tertentu, dapat berperan sebagai leverage (pengungkit) profitabilitas perusahaan. Kekurangan dana operasional perusahaan dapat mengganggu aktivitas usaha perusahaan dalam perolehan laba, yang dapat berakibat pada turunnya profitabilitas. Penggunaan hutang jangka pendek dapat membantu memperlancar aktivitas operasi perusahaan dalam rangka memperoleh profit, sehingga berdampak positif pada kenaikan profitabilitas.

Sedangkan untuk mengetahui besar pengaruh Short-term Debt to Asset terhadap profitabilitas secara parsial, dapat dilihat dari nilai koefisien determinasinya, yaitu sebesar 58,98\%. Untuk menguji tingkat signifikansi dari besar pengaruh tersebut dapat dilihat dari nilai Sig sebesar 0,000 yang ternyata lebih kecil dari nilai $\alpha 0,05$, sehingga besaran pengaruh tersebut signifikan.

Berdasarkan hasil penelitian di atas, maka hipotesis yang menyatakan bahwa Short-term Debt to Asset berpengaruh terhadap profitabilitas dapat diterima dan pengaruhnya signifikan.

\section{Pengaruh Long-term Debt to Asset Terhadap Profitabilitas UMKM Kota Tasikmalaya}

Dari hasil output SPSS diperoleh nilai koefisien korelasi antara Long-term Debt to Asset dengan profitabilitas sebesar 0,452 yang menunjukkan keeratan hubungan antara Long-term Debt to Asset dengan profitabilitas tersebut masuk kategori sedang.

Nilai koefisien korelasi yang positif menunjukkan bahwa Long-term Debt to Asset berkorelasi positif dengan profitabilitas, hal ini menunjukkan bahwa semakin besar rasio Long-term Debt to Asset dalam batas tertentu maka akan semakin meningkatkan profitabilitas, dan sebaliknya, semakin kecil rasio Long-term Debt to Asset maka akan 
semakin kecil profitabilitas. Hal ini menunjukkan bahwa hutang jangka panjang, dalam batas tertentu, dapat berperan sebagai leverage (pengungkit) profitabilitas perusahaan. Kekurangan dana operasional perusahaan dapat mengganggu aktivitas usaha perusahaan dalam perolehan laba, yang dapat berakibat pada turunnya profitabilitas. Penggunaan hutang jangka panjang dapat membantu memperlancar aktivitas operasi perusahaan dalam rangka memperoleh profit, sehingga berdampak positif pada kenaikan profitabilitas.

Untuk mengetahui besar pengaruh Long-term Debt to Asset terhadap profitabilitas, dapat dilihat dari nilai koefisien determinasinya, yaitu sebesar 20,43\%. Untuk menguji tingkat signifikansi dari besar pengaruh tersebut dapat dilihat dari nilai Sig sebesar 0,016 yang ternyata lebih kecil dari nilai $\alpha 0,05$, sehingga besaran pengaruh tersebut signifikan.

Berdasarkan hasil penelitian di atas, maka hipotesis yang menyatakan bahwa Long-term Debt to Asset, berpengaruh terhadap profitabilitas dapat diterima.

\section{Pengaruh Total Debt to Asset Terhadap Profitabilitas UMKM Kota Tasikmalaya}

Dari hasil output SPSS diperoleh nilai koefisien korelasi antara Total Debt to Asset dengan profitabilitas sebesar -0,254, yang menunjukkan keeratan hubungan antara Total Debt to Asset dengan profitabilitas tersebut masuk kategori rendah.

Nilai koefisien korelasi yang negatif menunjukkan bahwa Total Debt to Asset berkorelasi negatif dengan profitabilitas, hal ini menunjukkan bahwa semakin besar rasio Total Debt to Asset maka akan dapat menurunkan profitabilitas, dan sebaliknya, semakin kecil rasio Total Debt to Asset maka akan meningkatkan profitabilitas. Hasil penelitian tersebut menunjukkan bahwa penggunaan hutang jangka panjang dan hutang jangka pendek secara bersamaan oleh UMKM kota Tasikmalaya dapat menurunkan profitabilitas perusahaan. Total hutang tersebut ternyata tidak mampu berperan sebagai leverage (pengungkit) profitabilitas, karena pinjaman yang terlalu besar akan meningkatkan risiko tidak terbayarnya beban tetap berupa bunga dan pinjaman pokoknya yang dapat berdampak pada penurunan laba (berdampak pada turunnya profitabilitas).

Untuk mengetahui besar pengaruh Total Debt to Asset terhadap profitabilitas, dapat dilihat dari nilai koefisien determinasinya, yaitu sebesar 6,452\%. Untuk menguji tingkat signifikansi dari besar pengaruh tersebut dapat dilihat dari nilai Sig sebesar 0,191 yang ternyata lebih besar dari nilai $\alpha 0,05$, sehingga besaran pengaruh tersebut tidak signifikan.

Berdasarkan pengujian tingkat signifikansi, maka hipotesis yang menyatakan bahwa Total Debt to Asset berpengaruh terhadap profitabilitas tidak dapat diterima. Hasil penelitian di atas, menunjukkan adanya pengaruh negatif total hutang jangka pendek dan jangka panjang atas aktiva perusahaan terhadap profitabilitas, namun pengaruh tersebut tidak signifikan, sehingga pengaruh negatifnya masih dapat diabaikan.

\section{KESIMPULAN DAN IMPLIKASI}

\section{Kesimpulan}

Berdasarkan hasil penelitian, maka dapat disimpulkan beberapa hal berikut ini:

Struktur modal UMKM di lingkungan kota Tasikmalaya secara rata-rata, menunjukkan bahwa aktiva atau aset perusahaan UMKM kota Tasikmalaya dibiayai dengan hutang jangka pendek sebesar 7,35\%, dibiayai dengan hutang jangka panjang sebesar $25,58 \%$, dan dibiayai baik dengan hutang jangka pendek dan hutang jangka panjang sebesar 29,6\%. 
Profitabilitas UMKM di lingkungan kota Tasikmalaya secara rata-rata menunjukkan nilai sebesar 76,91\%, yang artinya bahwa kemampuan UMKM dalam menghasilkan laba dari aktiva perusahaan yang digunakan sebesar 76,91\%.

Pengaruh struktur modal terhadap profitabilitas UMKM di Kota Tasikmalaya sebagai berikut: Short-term Debt to Asset berpengaruh positif dan signifikan terhadap profitabilitas UMKM di lingkungan kota Tasikmalaya, Long-term Debt to Asset berpengaruh positif dan signifikan terhadap profitabilitas UMKM di lingkungan kota Tasikmalaya dan Total Debt to Asset berpengaruh negatif namun tidak signifikan terhadap profitabilitas UMKM di lingkungan kota Tasikmalaya.

\section{Implikasi}

Penelitian ini dapat diimplikasikan pada beberapa hal, antara lain : hasil penelitian menunjukkan besar pengaruh penggunaan hutang jangka pendek lebih kuat daripada penggunaan hutang jangka panjang terhadap profitabilitas UMKM, maka penggunaan hutang jangka panjang atau pinjaman dari perbankan tidak cukup efektif untuk UMKM, namun lebih efektif penggunaan hutang jangka pendek berupa hutang usaha, contohnya hutang dalam pengadaan bahan baku secara kredit. UMKM sebaiknya memilih penggunaan hutang jangka pendek non perbankan untuk meningkatkan profitabilitasnya. UMKM juga sebaiknya menghindari penggunaan hutang jangka pendek dan hutang jangka panjang secara bersamaan, karena tidak efektif meningkatkan profitabilitas.

Implikasi untuk peneliti selanjutnya, diharapkan melakukan penelitian yang sama dengan lokasi penelitian yang berbeda, atau dengan menambahkan beberapa variabel penelitian seperti kompleksitas operasi perusahaan, promosi, efektifitas pemasaran, dan lain-lain.

\section{DAFTAR PUSTAKA}

Abor, J. 2005. The Effect of Capital Structure on Profitability: An Empirical Analysis of Listed Firms in Ghana. The Journal of Risk Finance 6 (5), 438-445.

Agus Sartono. 2011. Manajemen Keuangan (Teori dan Aplikasi). Yogyakarta : BPFE

Ali Kesuma. 2009. Analisis Faktor yang Mempengaruhi Struktur Modal serta Pengaruhnya Terhadap Harga Saham Perusahaan Real Estate yang Go Public, Jurnal Manajemen dan Kewirausahaan, Vol.11 No.1 Hal : 38-45, Maret.

Astuti, Kurniasih Dwi., Retnowati, Wulan., dan Rosyid, Ahmad. 2015. Pengaruh Struktur Modal Terhadap Profitabilitas (Studi Pada Perusahaan Go Publik yang Menjadi 100 Perusahaan Terbaik Versi Majalah Fortune Indonesia Periode Tahun 2010-2012). Jurnal Akuntansi, Vol, 2 No. 1 Juli 2015, Hal: 49-60.

Bambang Riyanto. 2010. Dasar - Dasar Pembelanjaan Perusahaan. Yogyakarta: BPFE.

Dedy Supianto, Witarsa, dan Warneri. 2012. Pengaruh Rasio Utang Terhadap Profitabilitas pada Perusahaan Makanan dan Minuman Terdaftar di BEI Periode 2008-2011. Jurnal Pendidikan dan Pembelajaran Untan, Vol.2 No. 1 Januari 2013. Hal: 2-13.

Gill, Amarjit., Biger, Nahum., dan Mathur., Neil. 2011. The Effect of Capital Structure on Profitability: Evidence from the United States. International Journal of Management Vol. 28 No. 4 Part 1 Dec 2011.

Kodrat, David Sukardi. 2009. Peranan Struktur Modal terhadap Profitabilitas. Jurnal Eksekutif Vol. 6 No. 1 Februari.

Mochammad Nazir. 2005. Metode Penelitian. Jakarta: Ghalia Indonesia. 
Munawir, S. 2010. Analisis laporan Keuangan Edisi keempat. Cetakan Kelima Belas. Yogyakarta: Liberty.

Ridwan Tobing dan Nirwana Tallanky, 2004. Kamus Istilah Akuntansi. Jakarta : Atalya Rilany Sudeco.

Said Kelana Asnawi dan Chandra Wijaya. 2005. Riset Keuangan, Pengujian-Pengujian Empiris, Jakarta: Penerbit PT Gramedia Pustaka Utama

Sugiyono. 2010. Statistik Untuk Penelitian, Edisi kesepuluh. Bandung: CV. Alfabeta.

Suharsimi Arikunto. 2010. Prosedur Penelitian Suatu Pendekatan Praktik. Jakarta: Rineka Cipta.

Warsono, Sony dkk, 2009. Corporate Governance Concept and Model. Yogyakarta: Center of Good Corporate Governance. 